\title{
Aboriginal English and Responsive Pedagogy in Australian Education
}

\author{
Ian G. Malcolm \\ Applied Linguistics, \\ Edith Cowan University, Western Australia
}

\section{Patricia Königsberg}

English as an Additional Language and Dialect, Department of Education, Western Australia

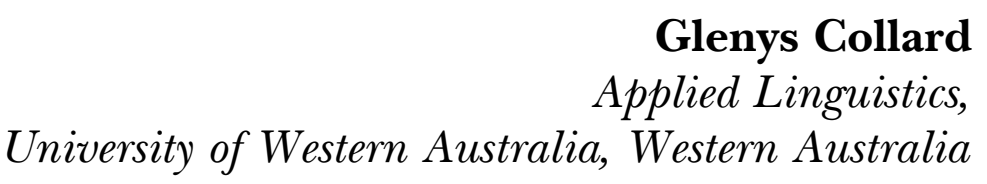

Abstract: Aboriginal English ${ }^{i}$, the language many Aboriginal and Torres Strait Islander students bring to the classroom, represents the introduction of significant change into the English language. It is the argument of this paper that the linguistic, social and cultural facts associated with the distinctiveness of Aboriginal English need to be taken into account in the English language education of both Aboriginal/ Torres Strait Islander and non-Indigenous students in Australia.

The paper illustrates seven significant changes of expression which Aboriginal English has made possible in English. It then proposes a "responsive pedagogy" to represent a realistic and respectful pedagogical response to the linguistic, social and cultural change which underlies Aboriginal English, drawing on current literature on second language and dialect acquisition and making frequent reference to materials which have been developed to support such pedagogy.

It is implied that only with a pedagogy responding to Aboriginal English as it is, and to its speakers, will a viable English medium education for Aboriginal and Torres Strait Islander people be enabled.

Keywords: Aboriginal English, Aboriginal EALD, responsive pedagogy and authenticity 


\section{English in Australian Education}

The English language is the assumed medium of education in Australian schools and English literacy is a fundamental required outcome of Australian education. However, English in Australia exists in a range of varieties: standard, Indigenous, ethnic, generational and regional (Blair \& Collins, 2001). While it is a reasonable expectation that most Australians will be able to switch between their own variety and the standard, the gap in achievement between Indigenous and non-Indigenous Australian students (Commonwealth of Australia, 2020) suggests that the division between the dialects of Indigenous and immigrant Australians is more profound than has been generally realized.

The reasons for the strong maintenance of a distinctive variety of English by Indigenous peoples of Australia may be traced back to the ways in which English was indigenized by Aboriginal and Torres Strait Islander Australians, through pidginization and creolization, before becoming an Australian dialect (see Malcolm, 2001). As shown through this process, Aboriginal English maintains for its speakers the strong social and environmental links which had been embedded in traditional Australian languages (see also Eades, 2013). It is, then, not surprising that it has been strongly maintained by its speakers as a variety distinct from Australian English.

For these speakers, the link between language, country, family and community is profound (see, e.g., Malcolm, 2018b). Lack of awareness of this fact has often entailed assumptions on the part of educators that, without targeted support, Standard Australian English (SAE) is as accessible to Aboriginal English speakers as it is to other Australians. This has led to making unreasonable demands on Aboriginal and Torres Strait Islander students with respect to classroom and national testing performance.

Aboriginal English is necessarily present in Australian education, since its speakers are among the students, but its presence is often not recognised, acknowledged or adapted to (Malcolm et al., 2002). Too often it is assumed that the communicative needs of Aboriginal and Torres Strait Islander speakers can be subsumed under provision and use of the standard dialect. It is, indeed, necessary for all students to receive, through their education, the option of a medium of expression which enables them to access the global culture, but such provision should not be at the cost of the loss of the dialect they bring to the 
educational setting, a dialect which represents the unique response of its speakers to the world around them (Eades, 1995) and constitutes the medium in which, according to Article 30 of the Convention on the Rights of the Child (United Nations 2009, p. 4) they are entitled to be taught to read and write.

It should be added that a better understanding of Aboriginal English is a desirable outcome of the education of all Australians, since it is necessary not only for Aboriginal and Torres Strait Islander speakers to operate with confidence in the context of the English of other Australians but for other Australians to appreciate the values underlying the maintenance of this dialect by its speakers.

Much of what we know about Aboriginal English (and indeed much that is drawn on in this paper) has come from linguistic data gathered from speakers of school age (see Department of Education, 2016; Kaldor \& Malcolm, 1991; Königsberg et al., (Eds.) 2012; Malcolm, 1979; Malcolm, 2002b; Malcolm et al., 1999b; Rochecouste \& Malcolm, 2003) but much has also been cited from research in other states (for a list of other sources, refer to Kaldor \& Malcolm, 1982, pp. 110-11; Malcolm, 2018b, pp. 2-6.). As observed by Angelo et al. (2019), it is important that descriptions of contact varieties include reference to how, for their speakers, they provide a culturally distinctive perspective on the world as they perceive it, or "how we speak round here" (Angelo et al., 2019, p. 36). The next section, drawing on both published materials and field notes, will illustrate some of the key ways in which, from the Aboriginal and Torres Strait Islander speaker's point of view, Aboriginal English represents an enhancement of the expressive power of English.

\section{What Aboriginal English Brings to the English language in Australia}

It is important to recognize that Aboriginal English is English. It is founded on the phonological, morphological, syntactic and semantic categories and processes that distinguish English from other languages. As further elaborated below, where Aboriginal English changes the language, it often does so by employing processes already operating in the language, but using them in different, or more extensive (or even, more consistent) ways. At one level, then, Aboriginal English is an alternative way of using the existing English system. At another level, however, Aboriginal English goes beyond the existing system, expanding the expressive 
possibilities of the language in response to cultural conceptual imperatives and sometimes drawing on transfer from traditional languages, or non-standard dialects of English, to achieve this (Malcolm, 2018b).

Our focus here will be on seven prominent ways in which Aboriginal English makes English a better vehicle for the expression of its speakers' world view. These are: 1. group inclusion, 2. environmental reference, 3. orientation to observation, 4. orientation to action, 5. enhancement of emphasis, 6. enhancement of immediacy and 7. cultural schematic reference.

\subsection{Group Inclusion}

One of the strongest delineating features of Aboriginal English is its ever-present awareness of the relevance of the group to the speaker and to what is being talked about. This corresponds to the fact that Australian Indigenous society is one of "high-context" (Hall, 1976), in which the situation, and the shared groupconsciousness, has a key role in communicating messages. Groupspecificity may be seen to underlie features of morphology, syntax, lexis and discourse. In many cases, the features illustrated below served the purpose of underlining group-specificity in the vernacular speech of other groups among those who had emigrated to Australia, and were retained for the same purpose by Aboriginal and Torres Strait Islander speakers of the language (Malcolm, 2018b, pp. 142-143).

\section{Morphology}

Extension of plural morphology to pronoun forms unmarked in SAE (thus making group reference less vague):

Do youse want to come to the pools? (Malcolm et al., 1999b, p. 49)

\section{Syntax}

Retrospective informative clause to support addressee comprehension:

He was driving along the Windmill run, 'cause he drives that slow, and he still comin' back ... (Rochecouste \& Malcolm, 2003, p. 30). 
Lexis

Lexical refinement to make culturally-relevant discriminations:

they shot ten kangaroos and ten boomers [i.e. ten boomers, indicating large male kangaroos. This refinement is culturally relevant as the meat from either will determine who it will be distributed to, the softer meat to the elders, the really tough meat to the dogs, etc.] (Königsberg \& Collard, 2007, p. 92).

camp [refers to staying somewhere overnight or for a longer time, rather than camping somewhere outside] We just camp then on the bus; camp out [staying outside]. And then after we camped out there (Königsberg \& Collard, 2007, p. 113; Malcolm, 2002a, p. 107).

Big shame [bashful] (Arthur, 1996, p.108) Shame job there (Sleep, 1996, p. 17). [A direct one-to-one translation of words such as "shame" from Aboriginal English to Standard Australian English may not reveal the complexity of its meaning as interpreted by Aboriginal and Torres Strait Islander speakers (Harkins, 1990, p. 158).]

Don't be shame [feel embarrassed] in front of me (Malcolm, 2002b, p. 87).

My auntie was cooking feed [she was cooking a meal] (Malcolm, 1999a, p. 46). You eat feed, you make feed, da's mean dinner, after you finish feed you put it in the sink and you wash it (Sharifian, 2001).

\section{Discourse}

Use of tags to elicit confirmation from group members:

Uncle Gary goes with them sometimes, unna (Königsberg \& Collard, 2007, p. 93).

That would've been solid, eh (Malcolm, 2002b, p. 79).

We jus' listened, you know (Malcolm, 2002b, p. 108).

You didn't see me there, eh (Harkins, 1994, p. 69).

Use of a confirmatory tag to signify agreement:

A: I hate that! 
B: Unna! (Research data for the project "Language and Communication Enhancement for Two-Way Education" from tape MG2 (Mullewa), 1994).

Use of affiliative tags as an expression of group relationship:

Come at me bro [I dare you to have a go at me!] (Adams, 2014, p. 10).

I bin dere boy (Malcolm, 2018b, p.111).

We goin right down 'ere, sister girl (Collard, 2011, p. 33).

Use of ting/thing as a pronoun to cover what is considered knowledge common to the group:

So we jump off the ting (Eagleson et al., 1982, p. 233).

They gave me envelope so..I put it in there..and I writ down what I wanted on the ting (Malcolm et al., 1999b, p. 56).

The teacher. Like..tries to correct us but we still don't know what she's..thing.. (Malcolm et al., 1999b, p. 56).

Acknowledgement of the group member who is the source of information given:

...my mum's grandfather told my mum's mum that then my mum's mum told me (Malcolm, 2018b, p. 124).

Signifying to the group that one has reached the end of one's turn:

That's it. That's the end. (Malcolm, 2002b, p. 108).

...and they shoot im then. Finish. (Eagleson et al., 1982, p. 236).

\subsection{Environmental Reference}

Aboriginal English speakers may make reference to the environment in distinctive ways, implying cultural activities and assumptions through morphology, syntax and lexis.

\section{Morphology}

The compound verb go for is used in relation to hunting:

They went for kangaroo (Harkins, 1994, p 68). 
Then we went lookin' for Turkeys but they w' all sleep and as we went for - oh yeah an we seen some wild cats (Malcolm, 2002b, p 92).

The combination of go with a verb or gerund implies "associated motion" (Koch, 2000):

We went camping out (Malcolm, 2002a, p. 119).

Two Yamatjis up dere...dey went shootin...(Rochecouste \& Malcolm, 2003, p. 24).

...we had to go show him (Malcolm, 2002b, p. 99).

Syntax

The expression from long way may be used to refer to distance from the speaker:

I bin hear it from long way (Königsberg \& Collard, 2007, p. 95).

Lexis

The term country relates to a person's place of belonging:

Where your country? (Vinson, 2008, p. 5).

\subsection{Orientation to Observation}

Observation is a valued activity in Aboriginal and Torres Strait Islander societies. Sharing and responding to observations on the immediate environment, sometimes referred to as 'speculative reporting' (Eades, 2013, p 70), has been shown to be a typical pattern of communication between speakers of Aboriginal English (see for example Collard, 2011; Malcolm, 2017, p. 164; Malcolm, 2018b, p. 9). The morphology and syntax of Aboriginal English reflect this preoccupation.

\section{Morphology}

Aboriginal English speakers will often modify the morphology to give, more precisely, an observer's perspective on what is being presented.

Irregular noun plurals may be made more explicit through the application of the regular plural suffix:

sixty mens (Malcolm, 1979, p. 35) 
Inexplicit pronoun possessives are made explicit through the application of the regular possessive suffix:

My cousin, e's name Greg (Malcolm et al., 1999b, p. 52).

Sometimes my mum - my dad goes out by hisself and my mum stays home. (Malcolm, 2002c, p. 120).

isself, theirself, theirselves (Malcolm, 2018b, p. 80)

Past tense may be made explicit through the application of the regular past tense suffix on irregular verbs:

I buyed an ice cream in a bucket (Malcolm, 1979, p. 88).

Adverbs/adjectives conveying manner and time tend to be explicitly distinguished from one another through suffixing:

Went wobbly way, like that (Königsberg \& Collard, 2007, p. 92).

...got up quick way (Königsberg \& Collard, 2007, p. 116)

dark time [when it is dark] (Malcolm et al., 2002, p. 50)

late time [when it is late] (Malcolm et al., 2002, p. 50)

\section{Syntax}

Languages have the capacity to provide orientation of utterances in time, space and the speakers' standpoint (Finch, 2000, p. 214). This feature is commonly referred to as deixis. Aboriginal English makes extensive use of deixis, in keeping with the need to uphold the conceptualisation of the speaker as an observer.

Deixis may be used in response to a proximity schema, referencing the subject matter to the location of the speaker:

A: Where d' ya people come from?

B: We come from dis side eeya (Malcolm et al., 1999b, p. 55).

In Granite Peak there, well we was goin' for walk (Malcolm, 1979, p. 59).

I 'aven't got a reading book 'ere (Malcolm, 1979, p. 113). 
Deixis may also be employed with a presentative function: an' 'e saw... saw dis bloke 'ere, sayin' "Ay, come over "ere" (Malcolm et al., 1999b, p. 52).

Deixis may also reference what is spoken about to elements in a shared locational schema. For example, in a seaside setting it is understood that there will be tides:

Dat tide bin start comin' in (Malcolm et al., 1999b, p. 55).

Deixis may also relate a speaker's utterance to a temporal schema:

But 'e finish now (Malcolm, 1979, p. 85).

Another way of supporting the status of the speaker as an observer is by giving stronger emphasis to descriptive phrases. Rather than situating adjectives or adjectival phrases before the noun, the speaker will delay them, by a process of post-clausal extension, giving them a greater level of independence:

we get five sheeps, fat one (Eagleson et al., 1982, p. 88).

man make that fire, smoky one (Eagleson et al, 1982, p. 88).

e got new muticar, red one (Butcher, 2008, p. 635).

an' dis kid walked along an' went to de toilet, little blond head one (Rochecouste \& Malcolm, 2003, p. 30)

Another syntactic modification is to isolate the subject which is in focus, bringing it to the left of the main clause, a process of preclausal extension, or topicalization:

Emu egg, I bin eating 'em (Curriculum Corporation, nd., p. 31).

This crow, he came right up to the veran-right next to the veranda (Rochecouste \& Malcolm, 2003, p. 22).

\subsection{Orientation to Action}

The following examples demonstrate how there is also emphasis in Aboriginal English on a need to modify English to heighten the way in which action is represented. 


\section{Morphology}

It is not uncommon in Aboriginal English for what is expressed in a noun in other Englishes to be expressed in the form of a verb. Thus, we have conversions such as:

I schooled [i.e., went to school] in Derby (Malcolm, 2002c, p. 32).

She blackeye[d] Amy [She gave Amy a black eye] (Malcolm, 2018b, p. 153).

They cheek 'em [They give them cheek] (Malcolm, 2018b, p. 153).

Syntax

Parataxis may be effectively employed in narrative, where the linkage between two clauses is by juxtaposition, without any conjunction, as in:

Den I 'ad a shot, miss 'im (Malcolm \& Rochecouste, 2000, p. 271).

...e took some blanket...Found 'im (Malcolm, 2018b, p. 124).

Lexis

Aboriginal English incorporates a pervasive conceptual shift towards using the term for the end point or intention, of an action to describe the action, as in:

Kill [i.e., hit] him in the neck (Koch, 1991, p. 99).

kilim [i.e., hit it] (Sharpe, 1977, p. 48).

My own mother grew me up [brought me up] (Kaldor \& Malcolm, 1991, p. 79).

My auntie was cookin' feed [i.e. a meal] (Malcolm, et al. 1999a, p. 46).

I'll drop [i.e., strike] you (Dutton, 1965, p. 170).

Learn [i.e., teach] 'im to talk Nyungar words (Königsberg \& Collard, 2007, p. 83).

You'll have to hot [i.e., heat] it up (Malcolm, et al., 1999b, p. 46). 


\subsection{Enhancement of Emphasis}

Aboriginal English has developed out of the need for communication between speakers of different languages. One of the features of such communication is that the interlocutors are not sure how well their utterances are being understood, and there is a natural tendency towards overstatement (Malcolm, 2018b, p. 112) and heightened emphasis.

\section{Morphology}

The superlative suffix est has been adopted into Aboriginal English as an expression of extent, rather than of maximization, as in:

bi-i-iggest mob o' emus [a lot of emus] (Rochecouste \& Malcolm, 2003, p. 30).

bi-i-iggest shark [a very big shark] (Eagleson et al., 1982, p. 88)

a brainiest kid [a very brainy kid] (Eagleson et al., 1982, p. 88)

Similarly, the adverb too, which expresses excess in other Englishes, may be used with the sense of extent in Aboriginal English:

she was too mean [i.e., she was very mean] (Malcolm, 1979, p. 40).

too many hair [i.e., a lot of] (Königsberg \& Collard, 2007, p. 94).

Increased emphasis may also be achieved by extending the use of the completive particle $-u p$, which can accompany verbs:

she taught him up (Königsberg \& Collard, 2007, p. 92).

learn it up (Königsberg \& Collard 2007, p.116; Malcolm, 2018b, p. 99).

listen up (Malcolm et al., 2002, p. 49).

share up (Malcolm, 2018b, p. 99).

Barry and Ellen got married up (McKenry, 1995, p. 40). 
Syntax

As shown in the following examples, emphasis is also achieved distinctively by verbal repetition:

bigges', bigges' hot rod, you know (Eagleson et al., 1982, p. 88).

but me now, me now, I bin running, running, running, running, running, running, running, running (Eagleson et al., 1982, p. 94).

And run, run, run, run, run... and we ran (Kaldor \& Malcolm, 1991, p. 78).

The force of an interrogative may also be strengthened by the use both of word order and a question tag:

Sir, c' I start, ini? (Malcolm, 1979, p. 114).

Lexis

In many cases, the lexis of Aboriginal English incorporates words which, either literally, or metaphorically, carry strong emphasis:

I jarred [scolded] him (Malcolm, 2002, p. 76).

Louise had a smash [fight] with her (Königsberg \& Collard, 2007, p. 107).

chargin' on (indulging in alcohol) (Königsberg \& Collard, 2007, p. 122).

they was doin a wicked noise (Malcolm et al., 2002, p. 45).

scorch 'im up [be strict on him] (Malcolm et al., 2002, p. 39).

we lie- don't look [pretend not to look] (Königsberg \& Collard, 2007, p. 107).

\section{Discourse}

At the discourse level, Aboriginal English speakers may achieve greater emphasis by parallelism, whereby information is conveyed twice in grammatically different ways:

Dey speared dese.. dese two wiypellas. Dey speared 'em (Rochecouste \& Malcolm, 2003, p. 33).

That's it. That's the end (Malcolm, 2002b, p. 108). 


\subsection{Enhancement of immediacy}

Aboriginal English achieves greater immediacy in relating what is being said to the experience it represents. Here, some examples are provided that show how, often, this is achieved by increasing the embodiment of the phenomenon referred to in the linguistic form of expression.

Phonology

Vowel lengthening, accompanied by pitch rise may be used to strengthen immediacy:

We tied it hi-i-igh up on a big tree (Königsberg \& Collard, 2007, p. 112).

They're ti-i-iny little round things (Malcolm, 1999a, p. 51).

We bin go wi-i-ight aroun' eberywhere (Malcolm, 1999a, p. 51).

Use may also be made of onomatopoeia:

Shot 'em two at the same place, boom, boom, boom (Königsberg \& Collard, 2007, p. 92).

\section{Morphology}

Aboriginal English speakers may give greater immediacy to their depictions by treating non-count nouns (which tend to convey abstractions) as count nouns (which convey direct experience):

these big grasses [i.e., this deep grass] (Malcolm, 2018b, p. 71).

germs can give you the flus (Malcolm, 1979, p. 7).

Personal pronouns are given greater immediacy by being attached to a nominal base (e.g. 'mob', 'fella'):

Us mob [we] bin drive it (Königsberg \& Collard, 2007, p. 96).

Where youfella went? (Kaldor \& Malcolm, 1985, p. 235).

In a similar way, an adjective can be given a nominal base (eg. 'one'):

He was big one (Malcolm, 2002b, p. 103). 
That kid clever one (Crugnale, 1995, p. 151).

Lexis

The lexis of Aboriginal English evokes schemas which are not a part of non-Indigenous English. Thus, Aboriginal English speakers will be aware of culturally-shared meanings behind such words as:

clear [free from any negative or undesirable spiritual associations] (Arthur, 1996, p. 20).

clever [spiritually powerful] These ain't nothing much... Not clever stories, anyway (Lucashenko, 2018, p. 299).

Lorna was talk us a story [evoking the cultural context of storytelling] (Gillespie, 1991).

solid [positively evaluated] (Malcolm et al., 1999a, p. 38).

and we went along [signaling a moving element in a narrative] (Malcolm, 2018b, p. 120).

\subsection{Cultural Schematic Reference}

The use of Aboriginal English entails the use of interactive conventions and speech events peculiar to the dialect. Studies of the differences between the ways in which Aboriginal and Torres Strait Islander and non-Indigenous students respond to texts played or read to them (Sharifian, 2001; Sharifian et al., 2012) have shown that, in order to interpret what they hear, Aboriginal and Torres Strait Islander students draw on culturally-derived schemas. Where they are hearing a text from their own culture, Aboriginal and Torres Strait Islander students can anticipate the meanings associated with linguistic and cultural features embedded in the text (Sharifian et al., 2004; Sharifian et al., 2012). Where they are hearing a text from an unfamiliar culture, they often "reschematize" what they hear to enable it to fit the meaningproviding categories with which they are familiar. Cues as to meanings come from both the way in which the text is structured and the cultural allusions associated with the language used. For example, listening to a story about a 'wirli-wirli', or dust storm, a schema involving spirit action affected Aboriginal and Torres Strait Islander students', but not non-Indigenous students' interpretations (Sharifian et al., 2012, p. 50). 
What, then, does Aboriginal English bring to English? It enables access to an alternative cultural perspective, in which one's group awareness is heightened and one's relationship to the environment and what it communicates to the senses is more evident. It facilitates the expression of a less static view of experience and the generation of a response to the world which exhibits greater immediacy and emphatic impact. It provides cues to culturally distinct domains which provide mental templates by which inputs can be interpreted. Aboriginal English has been developed and maintained by its speakers because it is inseparable from the life and values they have inherited and want to retain.

\section{Aboriginal English and Responsive Pedagogy}

Culturally responsive pedagogy recognises that the euro-centric structures of education, while privileging and empowering those students aligned with these structures, may at the same time be failing to recognise as assets other knowledge systems and perspectives and thereby disempowering those for whom these are relevant (see Pirbhai-Illich et al., cited in Morrison et al., 2019). The existence, and the nature, of Aboriginal English have direct implications for the educator who is intending to employ a responsive pedagogy. So far, we have attempted to sum up some of the key ways in which Aboriginal and Torres Strait Islander speakers have modified English to enable it to convey the meanings that are important to them. In a sense, Aboriginal English is the outcome of learner-adaptation, on the part of the Aboriginal and Torres Strait Islander communities to which English came. To these speakers, the English they encountered was (as we have seen) an inadequate means of expressing essential cultural input such as:

a) the relevance of the group

b) relevant environmental awareness

c) evidence of observation

d) orientation to action

e) means of enhancing emphatic effect

f) experiential immediacy

g) conceptual relevance.

A responsive pedagogy will respectfully take these matters into account, recognizing that responsibility lies with the educator to adapt to the students' language, rather than vice-versa. It will 
"actively value, and mobilize as resources, the repertoires and intelligences that students bring to the learning relationship" (Morrison, et al., 2019, p. V).

In the light of what we know about Aboriginal English and what it contributes to English, we need to ensure its speakers feel safe to use it in schooling. To do this we need to develop a pedagogy that enables new knowledge to be generated through this dialect, and to be expressed as part of the repertoire of Aboriginal and Torres Strait Islander speakers. Such a pedagogy would be responsive to the linguistic, social and cultural reality of Aboriginal and Torres Strait Islander language use (as outlined in the seven features in section 2 , above), while also responding to contemporary trends in bi/multilingual and bi/multidialectal education. It is important to recognize that language entails social and cultural practices. The responsive pedagogy we need, with respect to English instruction, should have four areas of relevance and application:

1. linguistic authenticity, 2. social authenticity, 3. cultural authenticity and 4 . the enablement of global access. We will briefly expound these, with some reference to where they are being exemplified.

\subsection{Linguistic Authenticity}

It has been observed by Guenther et al. (2014, p. 13), on the basis of widespread findings from remote schools, that local Aboriginal people regard the school as an "island of culture" from which students hop off when school is out. There is a lack of authenticity in education which does not carry over into the learners' real life. Linguistic authenticity entails being true to the form of English which Aboriginal and Torres Strait Islander speakers have developed to embody the way in which they see the world. In a context where SAE is also present, this involves the ongoing development of students' communicative skills, firstly through awareness that what a student wishes to express may not be aligned to a default standard English expectation, secondly through exposure to a wide range of examples of how ideas can be expressed in various ways in English and thirdly, through the provision of meaningful feedback on the students' attempts to create meaning in a language that applies alternative conceptualisations. This requires an interest in the students' language, knowledge of how this language differs from what is considered standard, as well as knowledge of standard Australian 
English (Education Department of Western Australia, 1999). It also includes a need for safety: safe spaces where learners feel supported and respected, where they know they won't be judged or laughed at (Harrison, 2008, p. 150; Perso \& Hayward, 2015 p. 206) and it involves Aboriginal and Torres Strait Islander students becoming aware of the distinctiveness of their dialect (Angelo et al., 2019; Konigsberg \& Collard, 2007; Konigsberg et al., 2012; Miller, 2020; and Sharifian et al., 2012, pp. 74-94 offer ways of achieving this). Likewise, for non-Indigenous students, language authenticity involves recognizing that their dialect is not the only English. It requires non-Indigenous students acquiring receptive skills that enable them to understand Aboriginal English speakers better. This is in line with the Australian Curriculum which requires students to learn that language varies according to setting and audience, personal and social identities (ACARA, 2009) and further supports linguistic authenticity in the classroom (Königsberg et al., 2012).

\section{Home Language Recognition}

Responsive pedagogy will avoid monolingual and SAE monodialectal bias and be inclusive of the home language Aboriginal and Torres Strait Islander students bring to the classroom (Konigsberg et al., 2012, Focus Area 10, pp. 9-30). As such, it will use its approach to language to "unite people from different cultures" (Harrison, 2008, p. 9). Receptive competence in Aboriginal English will be expected of all students (Grote, 2002, p.134) and provision will be made for all students to use language which will enable "a sense of ownership over meaning making" (Norton, 2014, p. 110). Acquisition of the standard language or dialect will be seen as additive, not replacive (Konigsberg et al., 2012; Siegel, 2010, p. 208 and Sridhar, cited in May, 2014, p. 8). This requires opportunities for the student to use Aboriginal English for free self-expression, for the processing of thoughts and for the sharing of understandings with others. When students are using Aboriginal English in this way, it is important that their English not be corrected. In teaching SAE, teachers should be careful to explain to students that any correction of errors in SAE will only occur when the tasks explicitly require performance in SAE.

The significance of home language as the repository of habitus, or "embodied dispositions or ways of viewing and living in the world, enabling expression of identity" (May, 2014, p. 12) will be given due recognition, as natural expression in the home 
language is accommodated and valued.

Teaching will be guided by the "interdependence hypothesis" (Cummins 2000; Grote 2002, pp. 130-131; Gibbons, 1991, p. 6) whereby the learner's home language skill, especially in literacy, is seen as contributing to learning another language or dialect. Gibbons (2009, p. 59) uses the term "Janus Curriculum" to denote a curriculum which entails looking backwards to language already learned as well as forwards to new learning. Clearly, the relevance of the learner's home language to the language they are learning makes the role of the "bilingual helpers" (Gibbons, 1991, p. 66) in the classroom central.

Strategies need also to be followed to help teachers "getting to know learners" (Education Department of Western Australia, 1999; Konigsberg et al., 2012, p. 68) so that they may be fully informed on the students' language backgrounds and how they adapt to different audiences, across different situations and to different contexts.

\section{Repertoire Recognition}

Where students are accustomed to diversity of linguistic practice (heteroglossia), it is appropriate that such practice be recognized in the classroom (Blackledge et al., 2014, p. 194).

Students' language awareness may need to be raised in that they may initially not be aware that their home and school dialects are distinct (Berry \& Hudson, 1997; Perso \& Hayward, 2015, p. 89). Part of repertoire recognition is helping students to be aware of their existing dependence on translingual means of making meanings (Blackledge et al., 2014, p. 195; Canagarajah, 2014, p. 91; Garcia, 2015; Harkins, 1994).

As students are given opportunity to draw on their bi/ multilingual repertoire, they will express their bi/multilingual identity (Garcia \& Flores, 2014, p. 162; Wi, 2014, p. 167). As their awareness of the distinct differences in features between Aboriginal English and SAE grows, they will be able to increase their competence in keeping the two dialects apart when this is necessitated for academic achievement.

\section{New Language Exposure}

Responsive pedagogy recognizes language use as "a major principle of language development" (Gibbons, 1991, p. 26). This means that the need to communicate will precede, and lead to, the need to know the relevant rule systems. Exposure to the target 
language/dialect can be expected to provoke students to developing hypotheses about how it operates (Gibbons, 1991, p. 9; Lightbown \& Spada, 1993, pp. 7, 24, 54). Recognition of dialect difference lends further support to the developing understanding of alternative linguistic rules and how to apply them.

For the exposure to the target language/dialect to be effective, it is important that it be made comprehensible to the learners (Krashen, 1985). It is also important that the language exposure be "integrative" (Siegel, 2010, p. 206), that is, associated with the relevant content. This is best achieved when working with Aboriginal and Torres Strait Islander staff or students to ensure that content of what is being said is adequately interpreted by both teachers and students. This requires use of the students' first language, as supported by research which shows that use of first language makes learning of an additional language more effective (see for example research by Avery, 2013; Butzkamm, 2011; Wells Lindfors, 1991; Malcolm, 1982; Peltier, 2010; Scarino, 2011; Scott \& de la Fuente, 2008; Siegel, 2010) and that without it, students are likely to be disadvantaged in many ways (see for example research by Cheshire \& Edwards, 1998; Heit \& Blair, 1993 and Sharifian, 2005).

\section{New Language Support}

For the student to learn the new language it is necessary for the teacher to draw the learner's attention to contextually appropriate target forms and structures through highlighting them in interaction (scaffolding) (Gibbons, 2009, pp. 51, 87, 114; Harrison, 2008, p. 39; Perso \& Hayward, 2015, pp. 128, 258 and Sharifian et al., 2012, pp. 74-94). This must occur through curriculum content for which a learner has taken interest (Harackiewicz, 2016). The teacher can also provide support by verbalizing what might normally be assumed, with respect to patterns of interaction, so that "thinking is made visible" (Angelo et al., 2019; Gibbons, 2009, p. 35, c.f. Perso \& Hayward, 2015, p. 144).

To facilitate learning by using the language, the teacher may need to "restructure the learning environment" so that it is appropriate for the kinds of interaction being practised by role plays or real-life opportunities in a range of settings (Konigsberg et al., 2012: Focus Area 3, p. 62, Focus Area 10, p. 27).

It is necessary for learning to be assessed, but, with sensitivity to the cultural appropriateness of the means used (Malcolm, 2011; Perso \& Hayward, 2015, pp. 171, 174). If the home language is 
entailed in the learning process, it should not be completely excluded from the means of assessment. In other words, if the assessment requires evidence of students' understandings of new concepts learned, the expression of these should be accepted in Aboriginal English and students should not be penalized for not using standard English in these instances.

\subsection{Social Authenticity}

Due to differences in valued behaviours at school from those valued in the family, many Aboriginal and Torres Strait Islander children start school on the backfoot (Taylor, 2011). Social authenticity means taking account of such differences in behaviours and associated language. A classroom that favours an interactive setting to support an increase in peer communicative initiatives is vital (Gibbons, 1991, p. 27). This also supports peer learning which is in keeping with the principle of affiliation, whereby, "in Indigenous cultures the needs of the group are more important than the needs of the individual" (Perso \& Hayward, 2015, p. 63).

Many activities can be implemented by the students in groups and when they are organized into two-way teams (i.e., teams involving speakers who know the target language and those who are learning it) (Konigsberg et al., 2012, Facilitator's Guide, p. 13; Focus Area 4, pp. 53-60). To make this even more effective, where possible, it is important if Aboriginal and Torres Strait Islander and non-Indigenous teaching can demonstrate for the groups the principle of co-leadership (Konigsberg et al., 2012, Focus Area 10, p. 24), involving the following:

\section{Teacher-student interaction}

For a free-flow of information to be achieved in reciprocal ways, it is important that teachers and their students view themselves as "co-learners" (Wei, 2014, p. 168), in that the exchange between them is not one-way. As Perso \& Hayward, (2015, p. xxvi), put it, you (the teacher) may need to learn "a perception of yourself as a humble learner rather than an all-knowing teacher." Students will be willing and even keen to share if they feel valued and respected and if they can see there is a genuine interest in what they have to say.

\section{Interaction with community members}

The school is but one element in the lives of its students, and needs to be seen within the context of the students' wider 
experiential repertoires. Especially - though not exclusively - in more remote schools, the school's "embeddedness in the community" (Disbray \& Bauer, 2016, p. 37) needs to be upheld. Social authenticity is maintained if learners can feel and see an active interest and participation by family and community. The report on Closing the Gap (Commonwealth of Australia, 2020, p. 58) noted: "Students thrive at schools that engage with communities, provide a culturally inclusive curriculum with appropriate support, and have skilled teachers with high expectations."

\section{Collaboration}

Classroom collaboration is essential. This requires classroom language use to be oriented to group-supportive activities, through (but not limited to):

- Establishment of a "situation-oriented and participatory view of communication" (Leung, 2014, p. 124) entailing language use for group tasks;

- Joint construction of understanding and knowledge by teachers and students (Gibbons, 2002, p. 15);

- Reading as a shared activity (Harrison, 2008, p. 82); and

- Engaging students in "authentic ['real-world-like'] tasks" (Gibbons, 2009, pp. 12, 34).

\section{Message abundancy}

Message abundancy is a term that has been used by Perso \& Hayward (2015, p. 131) to refer to the objective of involving students in multi-modal communicative activities which will extend, and help to authenticate, their language learning. Language rich activities can be incorporated in a range of language modes, including, for example, speaking, story-telling, writing, reading, viewing (charts, maps, photos, diagrams, symbols, etc.), engaging with digital communication and video resources, and extending to non-verbal communication.

\section{Contextualisation}

The social authenticity of language pedagogy is evidenced in the way it views language "not as a system of discrete sets of skills but as a series of social practices and actions that are embedded in a web of social relations" (Garcia \& Flores, 2014, p. 148). The importance of contextualization is particularly relevant to Aboriginal and Torres Strait Islander learners, who are sensitive 
not only to the social context but also to "land links", working with "lessons from land and nature" (Yunkaporta, in Perso \& Hayward, 2015, p. 124).

As can be seen from the way Aboriginal and Torres Strait Islander speakers have adapted English to their way of life (see learner adaptations a-g, above), for language to be socially authentic to Aboriginal and Torres Strait Islander speakers it needs to be strongly referenced to the social and environmental context in which it is used. This means, for the teacher, a need to resist talking in abstractions and to become more sensitized to social and environmental contextual features, involving observation, awareness of country, group relationships and shared experience.

\subsection{Cultural Authenticity}

Teaching that is culturally authentic will show due respect for the culture that is receiving the new linguistic input and for the culture which generated the language being taught. Neither culture will be made dominant, but students of diverse origins will be shown, and expected to show, "empathy in being able to see the world from the other's perspective" (Perso \& Hayward, 2015, p. xxvi). Acknowledging the culture of the traditional area in which the learning occurs, is not only respectful but fosters reconciliation and understanding for historical developments. Guenther and his co-authors (2014, p. 13) found, in research into the aspirations and expectations of schooling among educators in remote schools, that non-locals commented more on academic outcomes and locals more about "listening to and working with the community and families so they can show the way forward." The view of the local people should be incorporated where possible, not only in remote settings, since its importance has also been attested by Aboriginal and Torres Strait Islander people from rural and metropolitan settings (Department of Education of Western Australia, Perth, 2016).

\section{Drawing on traditional learning}

In the case of Aboriginal and Torres Strait Islander learners, pedagogy which is culturally authentic will draw on the traditional modes of learning which have been preserved in Aboriginal and Torres Strait Islander cultures. As we have observed above, in noting what Aboriginal English has brought to English, we have been made aware of some of the ways in which traditional 
approaches to experience, such as observation, group inclusion and environmental awareness have been implanted into English. More particularly, with respect to learning, Harris (1980, pp. 77-97), endorsed by Harrison (2008, pp. 17-18), has drawn attention to a number of traditional informal learning strategies, including:

- learning by observation and imitation;

- learning by personal trial and error, rather than verbal instruction;

- learning by real life activities, rather than theory,

- and learning by context-specific activities.

Culturally authentic pedagogy for Aboriginal and Torres Strait Islander learners will give these orientations due regard.

\section{Community links}

One of the findings of the report on the state of reconciliation in Australia was that cycles of failure in Aboriginal and Torres Strait Islander education had been caused by the assumption of control only by non-Indigenous educators. The report argued that " $\mathrm{t}] \mathrm{o}$ break these cycles, Aboriginal and Torres Strait Islander people must be involved in decision making to develop comprehensive, preventative, long-term approaches" (Reconciliation Australia, 2016 , p. 17). The relevance of the community to the education which is imparted to its children cannot be underestimated. The education needs to be situated in a way that values the culture (Perso \& Hayward, 2015, p. 47) and in a way that may enhance it. As Yunkaporta, put it: "We bring new knowledge home to help our mob" (Perso \& Hayward, 2015, p. 124). The Two-way Science project, developed in remote Aboriginal schools as a part of the CSIRO Indigenous STEM Education Program, recognizes the relevance of traditional cultural knowledge to science and "involves Aboriginal people making decisions about the direction and content of the school learning program" (Deslandes et al., 2019 , p. 6). An essential element of two-way science is the input of Indigenous ecological knowledge and on-country learning, presented in a way which complements new knowledge.

\section{Cultural imagery}

Every culture brings its own mental imagery to the understanding and communication of experience. We referred above (in 2.7) to the ways in which Aboriginal English has brought distinctive 
schemas into its speakers' English communication. Culturally responsive education will recognize the relevance of cultural metaphors and schemas (Malcolm, 2018b, pp. 140-142; Perso \& Hayward, 2015, p. 48) and use them to enhance learning (Konigsberg et al., 2012, Focus Area 4.5).

\subsection{Global access}

Nothing we have said about the relevance of cultural links should be taken to imply that wider world knowledge should be considered irrelevant to Aboriginal and Torres Strait Islander students. As Perso and Hayward (2015, p. 77) have noted, "Most Aboriginal and Torres Strait Islander parents just want their children to have the same educational opportunities as white children, but not at the expense of their culture." Similarly, Northern Territory Aboriginal Wunungmurra is cited by Bat and Shore (2013, p. 10) as stressing the need to "[p]repare our young people for the modern world without disadvantage."

The concept of "both worlds" or "two-way" learning has, indeed, been generated by Aboriginal and Torres Strait Islander communities who recognize that the wider world is not only relevant to the education they need but also relevant to the wider world and therefore, it should be a part of a collaborative and mutually respectful inquiry into living in the culturally complex world they and all other learners inhabit.

\section{Conclusion}

We would, then, support the concept of responsive pedagogy as a linguistically, socially and culturally realistic and unifying way of educating for cultural maintenance, global incorporation and global participation. Too many times in the past, good intentions for Aboriginal and Torres Strait Islander education have been primarily generated from non-Indigenous sources. Pedagogy which is responsive to the actualities of Aboriginal and Torres Strait Islander communicative experience needs to be, we would argue, the essential way for the future.

In brief, a responsive pedagogy for Aboriginal and Torres Strait Islander students will be grounded in a respectful understanding and incorporation in the teaching process, of the culture which these students represent and have built into the way in which they use English. Such a pedagogy needs to have a place for the students' use of their own English as well as the provision of the English which will enable them to access needs beyond 
those within their own community.

Responsive pedagogy involves, on the part of educators, learning from the linguistic, social and cultural evidence of Aboriginal English (as outlined above) and interacting with members of the community as to appropriate ways of meeting their needs. It corresponds to the aspiration put forward, by the Department of the Prime Minister and Cabinet Closing the Gap Report 2020 which recognises the need for "a process that is truthful, strengths-based, community-led and that puts Aboriginal and Torres Strait Islander people at the centre" (Commonwealth of Australia, 2020, p. 3).

\section{References}

Australian Curriculum, Assessment and Reporting Authority [ACARA], (2009). The Australian Curriculum: English Foundation to Year 10 English.

Adams, K. (Ed.) (2014). Koorified: Aboriginal Communication and Well-Being. Fitzroy, Vic.: The Public Health and Research Unit, Victorian Aboriginal Community Controlled Health Organization (VACCHO) and the School of Nursing and Midwifery, La Trobe University.

Angelo, D., Fraser, H., \& Yeatman, B. (2019). The Art of Recognition: Visualising contact languages with community vernacular language posters. In Babel 54 (1-2), 43-36.

Arthur, J.M. (1996). Aboriginal English: A Cultural Study. Melbourne: Oxford University Press.

Avery, T. S. (2013). The Pedagogical Potential of Codeswitching. (MA TESOL essay) Sookmyung Women's University, Seoul, Korea.

Bat, M. \& Shore, S. (2013). Listening Differently: An exploration of grey literature about Aboriginal teacher education in the Top End of the Northern Territory. Darwin: Charles Darwin University.

Berry, R. \& Hudson, J. (1997). Making the Jump: A resource book for teachers of Aboriginal students, Catholic Education Office, Kimberley Region, Western Australia.

Blackledge, A., Creese, A., \& Takhi, J. K. (2014). Beyond multilingualism: heteroglossia in practice. In Stephen May (Ed.) The Multicultural Turn: Implications for SLA, TESOL and Bilingual Education. New York/London: Routledge, 191-215. 
Blair, D. \& Collins, P. (Eds.). (2001). English in Australia. Amsterdam/Philadelphia: John Benjamins.

Butcher, A. (2008). Linguistic aspects of Australian Aboriginal English. Clinical Linguistics and Phonetics 22 (8): 625-642.

Butzkamm, W. (2011). Why make them crawl if they can walk? Teaching with mother tongue support. Language Teaching. Tübingen: Gunter Narr Verlag. RELC Journal, 42(3), 379391.

Canagarajah, S. (2014). Theorizing a competence for translingual practice at the contact zone. In Stephen May (Ed.). The Multicultural Turn: Implications for SLA, TESOL and Bilingual Education. New York/London: Routledge, 78-102.

Cheshire, J. \& Edwards, V. (1998). Knowledge about language in British classrooms: Children as researchers. In A. EganRoberson and D. Bloome (eds). Students as Researchers of Culture and Language in Their Own Communities. Cresskill, NJ: Hampton Press, 191-214.

Collard, G. (2011). A Day in the Park. Perth: Department of Training and Workforce Development, Western Australia.

Commonwealth of Australia, Department of the Prime Minister and Cabinet. (2020). Closing the Gap Report 2020. Canberra: Commonwealth of Australia.

Crugnale, J. (compiler (1995). Footprints Across our Land: Short stories by senior Western Desert women. Broome: Magabala Books.

Cummins, J. (2000). Language, Power and Pedagogy: bilingual children in the crossfire. Clevedon: Multilingual Matters.

Curriculum Corporation (n.d.). Langwj Comes to School: promoting literacy among speakers of Aboriginal English and Australian Creoles, Department of Employment, Education and Training, Canberra.

Department of Education of Western Australia, Perth (2016). Aboriginal English Storybooks. Videos accessible through Youtube: watch?v=2a2E695JTe8; https://www.youtube.com/ watch? $=8 \mathrm{VbZw} 21 \mathrm{v} 0 \mathrm{Tk}$; https://www.youtube.com/ watch?v=nqT-J3nslRE. https://www.youtube.com/

Deslandes, C., Deslandes, S., Broun, D., Hugh, C., Walsh, F., Bradshaw, F. \& Griffith, J. (2019). Two-Way Science: An Integrated Learning Program for Aboriginal Desert Schools. 
Clayton South, Vic.: CSIRO Publishing.

Disbray, S. \& Bauer, R. (2016). A place to learn and work: Yuendumu Learning Centre. Darwin: Northern Institute, Charles Darwin University. Learning Communities:

International Journal of Learning in Social Contexts, 19 Special Issue, 26-45.

Dutton, T. E. (1965). The Informal English speech of Palm Island Aboriginal Children, North Queensland. M.A. thesis, University of Queensland, Brisbane.

Eades, D. (1995). Aboriginal English, PEN 093, Primary English teaching Association Australia.

Eades, D. (2013). Aboriginal Ways of Using English, Aboriginal Studies Press, ACT.

Eagleson, R. D., Kaldor, S. \& Malcolm, I. G. (1982). English and the Aboriginal Child. Canberra: Curriculum Development Centre.

Education Department of Western Australia, Perth, (1999). Solid English. Perth. ISBN $073073854 \mathrm{X}$.

Finch, G. (2000). Linguistic Terms and Concepts. London: Macmillan.

Garcia, O. (2015). Critical multilingual language awareness and teacher education. In Cenoz, J. et al. (Eds.). Language Awareness and Multilingualism, Encyclopedia of Language and Education. Switzerland: Springer, 1-17.

García, O., \& Flores, N. (2014). Multilingualism and common core state standards in the United States. In Stephen M. (Ed.). New York/London: Routledge. The Multicultural Turn: Implications for SLA, TESOL and Bilingual Education 147-166.

Gibbons, P. (1991). Learning to Learn in a Second Language. Newtown, N.S.W.: Primary English Teaching Association.

Gibbons, P. (2002). Scaffolding Language, Scaffolding Learning: Teaching Second Language Learners in the Mainstream Classroom. Portsmouth: Heinemann.

Gibbons, P. (2009). English Learners, Academic Literacy and Thinking: Learning in the Challenge Zone. Portsmouth: Heinemann.

Gillespie, K. (1991). McLaren Creek- The Children and their English. Canberra: Australian National University. B.A. Honours thesis.

Grote, E. (2002). Two-Way Learning and Two Kinds of Power. In Konigsberg, P. \& Collard, G. (Eds.). Ways of Being, Ways of Talk. East Perth: Department of Education and Training, Western Australia,125-138. 
Guenther, J., Milgate, G., O’Beirne, P. \& Osborne, S. (2014). Aboriginal and Torres Strait Islander aspirations and expectations of schooling in very remote Australian schools. Australian Association for Research in Education/New Zealand: Association for Research in Education Conference paper.

Hall, E. T. (1976). Beyond Culture. New York: Anchor Books.

Harkins, J. (1990). Shame and shyness in the Aboriginal classroom: A case for practical semantics. Australian Journal of Linguistics, 10, 293-306.

Harkins, J. (1994). Bridging two Worlds: Aboriginal English and crosscultural understanding, University of Queensland Press, St Lucia, Queensland.

Harris, S. (1980). Culture and Learning: Tradition and Education in Northeast Arnhem Land. Darwin: Norther Territory Department of Education.

Harrison, N. (2008). Teaching and Learning in Indigenous Education. South Melbourne: Oxford University Press.

Heit, M. and Blair, H. (1993). Language needs and characteristics of Saskatchewa Indian and Metis students: Implications for educators. In S. Morris, K. McLeod and M. Danesi (eds). Aboriginal Languages and Education: The Canadian Experience. Oakville, Ontario: Mosaic Press, 103-128.

Kaldor, S. and Malcolm, I. G. (1982). Aboriginal English in Country and Remote Areas: A Western Australian Perspective. In English and the Aboriginal Child (ed.). Eagleson, R. D., Kaldor, S. \& Malcolm, I. G. (1982). Canberra: Curriculum Development Centre.

Kaldor, S. and Malcolm, I. G. (1985). Aboriginal children's English - Educational implications. In Michael Clyne (ed.). Australia, Meeting Place of Languages. Canberra: Department of Linguistics, Research School of Pacific Studies, Australian National University, 223-240.

Kaldor, S. \& Malcolm, I. G. (1991). Aboriginal English - an overview. In Suzanne Romaine (Ed.). Language in Australia. Cambridge: Cambridge University Press, 67-83.

Koch, H. (1991). Language and communication in Aboriginal land claim hearings. In Suzanne Romaine (Ed.). Language in Australia. Cambridge: Cambridge University Press, 94-103.

Konigsberg, P. \& Collard, G. (eds.). (2007). Ways of Being, Ways of Talk. East Perth: Department of Education and Training. 
Konigsberg, P., Collard, G. \& McHugh, M. (Eds.). (2012). Tracks to Two-Way Learning. Perth: Department of Education and Department of Training and Workforce Development, Western Australia.

Krashen, S. (1985). The Input Hypothesis: Issues and implications. London: Longman.

Leung, C. (2014). Communication and participatory involvement in linguistically diverse classrooms. In Stephen May (Ed.). The Multicultural Turn: Implications for SLA, TESOL and Bilingual Education. New York/London: Routledge, 123146.

Lightbown, P. \& Spada, N. (1993). How Languages are Learned. Oxford: Oxford University Press.

Lucashenko, M. (2018). Too Much Lip. St Lucia: University of Queensland Press.

Malcolm, I. G. (1979). Classroom Communication and the Aboriginal Child: A Sociolinguistic Investigation in Western Australian Primary Schools. Ph. D. thesis, University of Western Australia, Volume 2.

Malcolm, I. G. (1982). Verbal interaction in the classroom. In Eagleson, R. D., Kaldor S. and Malcolm, I. G. (eds). English and the Aboriginal Child. Canberra: Curriculum

Development Centre, 165-192.

Malcolm, I. G. (1995) Language and Communication Enhancement for Two-way Education. Mount Lawley: Edith Cowan University and Education Department of Western Australia.

Malcolm, I, G. (2001). Aboriginal English: Adopted code of a surviving culture. In Blair, D. \& Collins, P. (Eds.) English in Australia. Amsterdam: John Benjamins, 201-222.

Malcolm, I. G. (2002a). Now You See It, Now You Don't. In Konigsberg, P. \& Collard, G. (Eds.) Ways of Being, Ways of Talk. East Perth: Department of Education and Training, Western Australia, 106-124.

Malcolm, I. G. (2002b). Aboriginal English Genres in Perth. Mount Lawley: Centre for Applied Language and Literacy Research and Institute for the Service Professions, Edith Cowan University.

Malcolm, I.G. (2002c). Indigenous imperatives in navigating language \& culture. International Journal of Learning, Vol 9: 25-44.

Malcolm, I. G. (2011). Issues in English language assessment of Indigenous Australians. Language Assessment Quarterly, 8 (2): 190-199. 
Malcolm, I. G. (2017). Embedding cultural conceptualisation within an adopted language. International Journal of Language and Culture 4, 2 pp149-169.

Malcolm, I. G. (2018a). The representation of Aboriginal cultural conceptualisations in an adopted English. International Journal of Language and Culture 5 (1): 66-93.

Malcolm, I. G. (2018b). Australian Aboriginal English: Change and Continuity in an Adopted Language. Boston/Berlin: De Gruyter Mouton.

Malcolm, I. G., Grote, E., Eggington, L. \& Sharifian, F. (2002). The Representation of Aboriginal English in School Literacy Materials, Centre for Applied Language and Literacy Research, Edith Cowan University.

Malcolm, I., Haig, Y., Königsberg, P., Rochecouste, J., Collard, G., Hill, A. \& Cahill, R. (1999a). Two-Way English: Towards More User-Friendly Education for Speakers of Aboriginal English. Mount Lawley, W.A.: Centre for Applied Language and Literacy Research and Education Department of Western Australia.

Malcolm, I., Haig, Y., Königsberg, P., Rochecouste, J., Collard, G., Hill, A. \& Cahill, R. (1999b). Towards More User-Friendly Education for Speakers of Aboriginal English. Mount Lawley, W.A.: Centre for Applied Language and Literacy Research and Education Department of Western Australia.

Malcolm, I. G. \& Königsberg P. (2007). Bridging the language gap in education. In Gerhard, L. \& Malcolm, I. G. (Eds.) The Habitat of Australia's Aboriginal Languages. Berlin/New York: Mouton de Gruyter, 267-297.

Malcolm, I. G., Königsberg, P., Collard, G., Hill, A., Grote, E., Sharifian, F., Kickett, A. \& Sahanna, E. (2002). Umob Deadly: Recognized and Unrecognized Literacy Skills of Aboriginal Youth. Mount Lawley, W.A., Centre for Applied Language \& Literacy Research and Institute for the Service Professions, Edith Cowan University.

Malcolm, I. G. \& Rochecouste, J. (2000). Event and story schemas in Australian Aboriginal English discourse. English WorldWide vol. 21, 2, pp. 261-289.

May, S. (Ed.) (2014). The Multicultural Turn: Implications for SLA, TESOL and Bilingual Education. New York/London: Routledge. 
McKenry, R. (1995). Academic Success for Speakers of Koorie English. Melbourne: Language Australia.

Miller, A. (2020). EAL/D Literacy Cycles to Success, R.E. \& A.J. Millar, Caloundra, Qld.

Morrison, A., Rigney, L.-A., Hattam, R., Diplock, A. (2019). Toward an Australian Culturally Responsive Pedagogy: A Narrative Review of the Literature. University of South Australia.

Norton, B. (2014). Identity, literacy and the multicultural classroom. In Stephen May (Ed.). New York/London: Routledge. The Multicultural Turn: Implications for SLA, TESOL and Bilingual Education, 103-122.

Peltier, S. (2010). Facilitating language and literacy learning for students with Aboriginal English dialects. Canadian Journal of Native Education, 32, 114-142.

Perso, T. \& Hayward, C. (2015). Teaching Indigenous Students: Cultural awareness and classroom strategies for improving learning outcomes. Sydney: Allen and Unwin.

Reconciliation Australia (2016). The State of Reconciliation in Australia. Summary. Kingston, A.C.T.: Reconciliation Australia.

Rochecouste, J. \& Malcolm, I. G. (2003). Aboriginal English Genres in the Yamatji Lands of Western Australia. Mount Lawley, W.A.: Centre for Applied Language and Literacy Research, Edith Cowan University.

Sharpe, M. C. (1977) Alice Springs Aboriginal English. In E. Brumby \& E. Vaszolyi (eds.) Language Problems and Aboriginal Education. Mount Lawley: Aboriginal Teacher Education Program, Mount Lawley College of Advanced Education, 45-50.

Scott, V. M. \& de la Fuente, M. J. (2008). What's the problem? Use of the L1 during consciousness-raising, form-focused tasks. The Modern Language Journal, 92(1), 100-113

Scarino, A. (2011). Absence as deficit in assessing intercultural capability. In Candlin, C. N. and Crichton, J. (eds). Discourses of Deficit. Basingstoke, UK: Palgrave Macmillan.

Sharifian, F. (2001). Association-Interpretation: A Research Technique in Cultural and Cognitive Linguistics', Applied Language \& Literacy Research (ALLR) 2(1). 
Sharifian, F. (2005). Cultural conceptualisations in English words: A study of Aboriginal children in Perth. Language and Education, 19, 74-88.

Sharifian, F., Rochecouste, J., Malcolm, I. G., Königsberg, P. \& Collard, G. (2004). Improving Understanding of Aboriginal Literacy: Factors in Text Comprehension. East Perth: Department of Education and Training, W.A.

Sharifian, F., Truscott, A., Königsberg, P., Malcolm, I. G. \& Collard, G. (2012). Understanding stories my way: AboriginalEnglish speaking students' (mis)understanding of school literacy materials in Australian English. Leederville, W.A.: Institute for Professional Learning, Department of Education.

Shore, S., Chisholm, P., Bat, M., Harris, B., Kell P. \& Reaburn, S. (2014). Pathways for Yolnu Teachers: Key messages for systems, teacher education institutions and educators. Casuarina: Charles Darwin University.

Siegel, J. (2010). Second Dialect Acquisition. Cambridge: Cambridge University Press.

Sleep, B. M. (1996). Aboriginal Language Research of Aboriginal Students and their Families of Crossway Lutheran School Ceduna South Australia. Ceduna: Crossways Lutheran School.

Taylor, A. J. (2011). Coming, ready or not: Aboriginal children's transition to school in urban Australia and the policy push, International Journal of Early Years Education, DOI:10.108 0/09669760.2011.602593.

United Nations (2009). Convention on the Rights of the Child. Geneva: Committee on the Rights of the Child.

Vinson, T. (2008). Some lexical variations of Australian Aboriginal English. Griffith Working Papers in Pragmatics and Intercultural Communication 1 (1): 1-6.

Wei, L. (2014). Who's teaching whom? Co-learning in multilingual classrooms. In Stephen May (Ed.). The Multicultural Turn: Implications for SLA, TESOL and Bilingual Education (pp. 167190). New York/London: Routledge.

Wells Lindfors, J. (1991). Children's language and learning (2nd ed.). Boston: Ally and Bacon. ISBN-13: 978-0807748855.

\section{Endnote}

(i) Aboriginal English" is the term used to denote "a range of varieties of English spoken by many Aboriginal and Torres Strait Islander people and some others in close contact with them which differ in systematic ways from Standard Australian English at all levels of linguistic structure and which are used for distinctive speech acts, speech events and genres" (Malcolm 1995, p 19). 
Ian Malcolm, Emeritus Professor of Applied Linguistics, Edith Cowan University, Western Australia. is widely recognized for his longstanding collaborative contributions to research into Aboriginal English as a linguistic, sociolinguistic and cultural phenomenon. He has been influential in bringing Aboriginal English research to international attention and, in association with Patricia Konigsberg and Glenys Collard, in developing policies and resources for two-way bidialectal education.

i.malcolm@ecu.edu.au

Patricia Königsberg is a teacher and a linguist with extensive experience teaching multilingual and bidialectal learners of all ages in a range of settings, including regional and remote areas of Australia. Patricia has actively coordinated Education-based research on Aboriginal English and two-way learning with Ian Malcolm and Glenys Collard. Patricia has a passion for empowering both Aboriginal and non-Aboriginal learners from diverse linguistic backgrounds. Patricia is currently Principal Consultant, English as an Additional Language/Dialect, at the Western Australian Department of Education.

patricia.konigsberg@education.wa.edu.au

Glenys Collard is a South West Nyungar woman and matriarch within her nuclear family of over 300 people. Glenys is an experienced teacher of all aspects relating to Aboriginal English and an Honorary Research Fellow at the University of Western Australia. She has co-authored numerous educational publications and academic papers, including three books written in Nyungar and Aboriginal English: "Kura", "Kwobba Keip Boya"and "A Day in the Park". Glenys' wide range of research experience in Nyungar language, Aboriginal English, culture and education has enabled her to contribute significantly to developments related to public sector policy and planning. 